\title{
ANEMIA DI KALANGAN MAHASISWI: PREVALENSI DAN KAITANNYA DENGAN PRESTASI AKADEMIK
}

\author{
Anindya Mar'atus Sholikhah ${ }^{1 *}$, Yetty Septiani Mustar², Agus Hariyanto ${ }^{3}$ \\ 1,2Jurusan Pendidikan Kesehatan dan Rekreasi, Fakultas Ilmu Olahraga \\ ${ }^{3}$ Jurusan Pendidikan Kepelatihan Olahraga, Fakultas Ilmu Olahraga \\ Universitas Negeri Surabaya \\ *E-mail: anindyasholikhah@unesa.ac.id
}

\begin{abstract}
Anaemia is still considered a serious public health problem, affecting more than $30 \%$ of the population worldwide. A female university student is one of the high-risk population, and this nutritional disorder will give a negative impact on health and affect students' academic performance. This study aims to identify the prevalence of anaemia among female university students in Surabaya and its relationship to academic achievement. This is an observational analytic study with a crosssectional design, involving 92 respondents who were selected using a consecutive sampling method. Data collected by using a questionnaire to obtain respondent characteristics, grade point average (GPA), and menstrual patterns. The measurement of haemoglobin levels carried out using the cyanmethemoglobin method. The results show that the prevalence of anaemia among female students was still quite high and there was a significant relationship between the incidence of anaemia and students' academic. Female students are one of the groups that are susceptible to anaemia, so it is essential to make various efforts to improve Hb levels by increasing the intake of foods high in iron.
\end{abstract}

Keywords: Anemia, Grade Point, College Student, Hemoglobin, Menstruation, Prevalence

\begin{abstract}
ABSTRAK
Anemia merupakan salah satu masalah kesehatan masyarakat yang serius, dimana lebih dari $30 \%$ penduduk dunia mengalami anemia. Sebagai salah satu kelompok rentan, anemia pada remaja tidak hanya berdampak pada kesehatan saja tetapi juga pada prestasi belajar. Penelitian ini bertujuan untuk mengidentifikasi prevalensi anemia pada mahasiswi di Kota Surabaya serta hubungannya terhadap prestasi akademiknya. Penelitian ini merupakan penelitian observasional analitik dengan desain cross-sectional, melibatkan 92 responden yang dipilih berdasarkan teknik pengambilan sampel secara consecutive sampling. Data karakteristik responden, indeks prestasi akademik, dan pola menstruasi diperoleh menggunakan kuesioner. Pengukuran kadar $\mathrm{Hb}$ dilakukan dengan metode cyanmethemoglobin. Hasil penelitian menunjukkan bahwa prevalensi anemia di kalangan mahasiswi sebesar $26,1 \%$ dan terdapat hubungan yang signifikan $(\mathrm{P}=0,040)$ antara kejadian anemia terhadap prestasi belajar mahasiswi berdasarkan indeks prestasi akademik. Mahasiswi sebagai salah satu kelompok yang rentan mengalami anemia, sehingga sangat penting untuk melakukan berbagai upaya yang dapat meningkatkan kadar $\mathrm{Hb}$ melalui peningkatan asupan makanan tinggi zat besi.
\end{abstract}

Kata kunci: Anemia, Hemoglobin, Indeks Prestasi, Mahasiswa, Menstruasi, Prevalensi 


\section{PENDAHULUAN}

Anemia merupakan masalah kesehatan masyarakat yang paling banyak dijumpai di berbagai belahan dunia, baik negara maju maupun negara berkembang ${ }^{1,2}$. WHO memperkirakan lebih dari $30 \%$ penduduk dunia menderita anemia, dan sebagian besar di antaranya berasal dari negara berkembang ${ }^{3,4}$. Anemia menjadi salah satu penyebab debilitas kronik di berbagai negara, yang mana kelainan ini mengakibatkan dampak besar terhadap kesehatan, ekonomi, kesejahteraan, dan berbagai aspek kehidupan lainnya ${ }^{5}$. Anemia dapat dialami oleh individu di setiap kelompok umur, namun anak-anak dan wanita usia subur merupakan kelompok yang paling rentan ${ }^{6}$. Dampak yang ditimbulkan dari anemia tidak hanya pada kesehatan saja, namun juga dapat memengaruhi pertumbuhan dan perkembangan fisik, serta menghambat perkembangan kognitif pada anak-anak usia sekolah ${ }^{7}$. Karena dampak yang ditimbulkan cukup besar, WHO menetapkan anemia sebagai salah satu dari 10 masalah kesehatan serius yang harus ditangani dengan segera ${ }^{8}$.

Anemia merupakan penyakit yang bersifat multifaktorial dengan penyebab yang sangat beragam, mulai dari faktor zat gizi (besi, asam folat, dan vitamin B12), dan faktor non zat gizi seperti keturunan (talasemia dan sickle cell), polutan (timbal), infeksi (malaria), autoimun (anemia hemolitik), malabsorpsi (achlorydria), penyakit kronis (kanker) dan faktor sosiodemografi ${ }^{9}$. Dari berbagai penyebab tersebut, defisiensi zat besi merupakan jenis anemia yang paling banyak ditemui, khususnya pada wanita usia subur seperti remaja dan ibu hamil ${ }^{10}$. Departemen Kesehatan pada tahun 2014 melaporkan bahwa prevalensi anemia pada remaja dan usia produktif sebesar $17-18 \%{ }^{1}$.

Sebagaimana pada kelompok usia produktif, anemia defisiensi besi pada remaja juga disebabkan oleh banyak faktor, antara lain kehilangan darah akibat perdarahan atau menstruasi setiap bulannya, asupan zat besi yang tidak adekuat, atau infeksi parasit ${ }^{6,8,11}$. Menstruasi merupakan penyebab utama kejadian anemia di kalangan remaja, yaitu kehilangan darah sebanyak $\pm 30 \mathrm{ml}$ dan zat besi $\pm 1,3 \mathrm{mg}$ dalam setiap siklusnya ${ }^{12}$. Zat besi merupakan mikronutrien penting yang sangat dibutuhkan tubuh untuk menjalankan berbagai proses metabolisme dan biokimia, membantu perkembangan otak, memelihara sistem kekebalan tubuh, serta mempercepat pengantaran rangsang melalui sel saraf ${ }^{13,14}$. Zat besi juga berperan dalam sintesis enzim dan hormon seperti dopamine dan serotonin. Kedua hormon ini terlibat dalam koordinasi motorik dan proses pemusatan perhatian atau konsentrasi, sehingga apabila kadar zat besi dalam tubuh rendah, maka kedua hormon ini tidak dapat disintesis secara maksimal. Pada akhirnya, remaja yang anemia dapat mengalami gangguan pada aspek kognitifnya yang dapat memengaruhi prestasi belajar. Jika kondisi ini 
terjadi dalam waktu yang lama, maka akan termanifestasi hingga ke fase dewasa, menyebabkan penurunan produktivitas dan efektivitas dalam bekerja ${ }^{9}$.

Di Indonesia, khususnya Kota Surabaya, anemia masih menjadi masalah kesehatan masyarakat yang perlu mendapat perhatian ${ }^{11}$. Hasil Riskesdas tahun 2013 menyebutkan bahwa prevalensi anemia di kelompok usia 1524 tahun sebesar $18,4 \%{ }^{15}$. Studi yang dilakukan oleh Setyono (2010) melaporkan bahwa prevalensi anemia di kalangan remaja Kota Surabaya juga masih cukup tinggi, yaitu sekitar $26,5 \%$, sedangkan pada remaja putri angkanya mencapai $33,3 \%{ }^{16}$. Program dan kebijakan pemerintah dalam mencegah anemia berfokus pada pemberian suplementasi tablet tambah darah (TTD) pada kelompok rentan. Namun, efektivitas dari program ini belum maksimal dalam mengurangi angka kejadian anemia di masyarakat ${ }^{17}$, yang dibuktikan dengan meningkatnya prevalensi anemia dari $37,1 \%$ menjadi 48,9\% berdasarkan survei terakhir yang dilakukan oleh Riskesdas pada tahun $2018^{18}$. Di samping itu, penelitian yang membahas masalah anemia pada remaja dan mahasiswa juga masih terbatas bila dibandingkan dengan penelitian sejenis yang dilakukan pada wanita dan anak$\operatorname{anak}^{10}$. Hal ini sangat disayangkan, mengingat remaja adalah generasi emas yang nantinya akan menjadi penerus bangsa. Oleh sebab itu, dilakukan penelitian ini untuk mengetahui prevalensi anemia pada mahasiswa di Kota
Surabaya, beserta hubungannya dengan prestasi belajar mahasiswa.

\section{METODE PENELITIAN}

Penelitian ini merupakan penelitian observasional analitik dengan desain crosssectional. Responden merupakan mahasiswa Universitas Airlangga yang dipilih berdasarkan teknik pengambilan sampel secara non-random (consecutive sampling), dengan kriteria inklusi: 1) terdaftar sebagai mahasiswi S1 aktif; (2) berusia maksimal 22 tahun; (3) tidak sedang mengonsumsi suplemen zat besi atau tablet tambah darah; (4) tidak sedang menstruasi pada saat pemeriksaan; dan (5) dalam kondisi sehat dan tidak sedang sakit penyakit infeksi (diare, TBC, malaria). Dari hasil pemilihan tersebut, diperoleh jumlah sampel sebanyak 92 orang.

Responden yang memenuhi kriteria inklusi, sebelum melakukan pengisian kuesioner diberi penjelasan mengenai informed consent dalam pelaksanaan penelitian ini. Kuesioner yang dibagikan berisi pertanyaan terbuka mengenai karakteristik responden (usia, tempat tinggal, status sosial ekonomi orang tua, indeks prestasi akademik kumulatif saat ini), asupan makan, dan status gizi, serta pola menstruasi (usia menarche, siklus menstruasi, dan lama menstruasi). Indeks prestasi akademik yang dilaporkan oleh siswa kemudian dilakukan cross check dengan data mahasiswa yang tersimpan dalam database kepegawaian fakultas untuk menjamin validitas data. 
Data mengenai asupan makan diperoleh dari hasil 24- $h$ food recall non-consecutive day yang dilakukan selama 2 hari, sedangkan data status gizi diperoleh dari Indeks Massa Tubuh menggunakan data berat badan dan tinggi badan. Pengukuran berat badan menggunakan digital bathroom scale, sedangkan tinggi badan diukur menggunakan microtoise dengan tingkat ketelitian 0,1 cm. Adapun pemeriksaan kadar hemoglobin dilakukan oleh tenaga perawat dengan mengambil darah sebanyak 3 cc dari pembuluh darah vena. Sampel darah tersebut kemudian ditampung di dalam tabung EDTA dan selanjutnya diuji menggunakan metode cyanmethemoglobin. Responden yang dikategorikan anemia jika hasil pemeriksaan menunjukkan kadar $\mathrm{Hb}<12 \mathrm{~g} / \mathrm{dl}$.

Data yang terkumpul kemudian dianalisis secara deskriptif dan inferensial menggunakan software SPSS. Analisis deskriptif dilakukan untuk mendapatkan gambaran karakteristik masing-masing variabel. Variabel yang berupa data kuantitatif disajikan dalam rerata dan standar deviasi, sedangkan variabel kategori disajikan dalam bentuk crosstabulation dengan

Tabel 1. Distribusi Karakteristik Responden ( $\mathrm{n}$ total =92)

\begin{tabular}{lcccc}
\hline \multicolumn{1}{c}{ Variabel } & $\mathrm{n}$ & $\%$ & Kadar $^{\mathrm{H}} \mathrm{Hb}^{*}(\mathrm{~g} / \mathrm{dl})$ & $p$-value \\
\hline Usia & & & & \\
$\quad<19$ tahun & 21 & 22,8 & 13,29 & \\
19-21 tahun & 54 & 58,7 & 13,35 & 0,255 \\
$\quad>21$ tahun & 17 & 18,5 & 13,65 & \\
Tempat tinggal & & & & \\
$\quad$ Kos & 52 & 56,5 & 12,85 & \\
Asrama & 13 & 14,1 & 12,30 & 0,047 \\
$\quad$ Bersama orang tua & 27 & 29,3 & 13,42 & \\
\hline
\end{tabular}

menampilkan persentase dan frekuensi. Uji ChiSquare dilakukan untuk mengetahui hubungan antara variabel pola menstruasi dan indeks prestasi akademik dengan status anemia, sedangkan independent t-test dan Anova oneway digunakan untuk mengetahui perbedaan kadar $\mathrm{Hb}$ di antara kelompok responden.

\section{HASIL DAN PEMBAHASAN}

Sebanyak 92 mahasiswa yang berumur 1822 tahun mengikuti penelitian ini, dengan komposisi umur paling banyak terdiri dari mahasiswa berusia 19-21 tahun $(58,7 \%)$. Karakteristik subjektif responden pada Tabel 1 menunjukkan bahwa sebagian besar mahasiswi tinggal di kos $(56,5 \%)$, berasal dari keluarga dengan status sosial-ekonomi menengah $(52,2 \%)$, memiliki pola makan memenuhi AKG $(54,3 \%)$, memiliki status gizi normal $(59,8 \%)$, dan memiliki prestasi yang baik (73,9\%). anemia adalah $26,1 \%$ atau 24 orang dari keseluruhan sampel pada Tabel 1. Berikut distribusi karakteristik responden. Adapun proporsi mahasiswi yang mengalami 


\begin{tabular}{lcccc}
\hline \multicolumn{1}{c}{ Variabel } & $\mathrm{n}$ & $\%$ & Kadar Hb$^{*}(\mathrm{~g} / \mathrm{dl})$ & $p$-value \\
\hline Status sosial-ekonomi orang tua & & & & \\
$\quad$ Rendah & 26 & 28,3 & 13,42 & \\
$\quad$ Menengah & 48 & 52,2 & 13,90 & 0,154 \\
$\quad$ Tinggi & 18 & 19,6 & 13,35 & \\
Asupan Makan & & & & 0,020 \\
$\quad$ Memenuhi AKG & 50 & 54,3 & 13,25 & \\
$\quad$ Tidak memenuhi AKG & 42 & 45,7 & 12,10 & \\
Status gizi & & & & \\
$\quad$ Kurus & 23 & 25,0 & 12,37 & \\
$\quad$ Normal & 55 & 59,8 & 13,85 & \\
$\quad$ Overweight & 14 & 15,2 & 12,60 & \\
Indeks Prestasi Kumulatif (IPK) & & & & \\
$\quad$ Cukup (<3.25) & 24 & 26,1 & 12,14 & \\
$\quad$ Baik (> 3.25) & 68 & 73,9 & 13,92 & \\
Status anemia & & & & \\
$\quad$ Anemia (Hb $<12$ g/dl) & 24 & 26,1 & 10,85 & \\
$\quad$ Tidak anemia (Hb $>12 \mathrm{mg} / \mathrm{dl})$ & 68 & 73,9 & 13,64 & \\
\hline
\end{tabular}

*kadar $\mathrm{Hb}$ disajikan dalam mean \pm SD

Hasil uji statistik pada Tabel 1 menunjukkan adanya perbedaan kadar $\mathrm{Hb}$ pada responden yang ditinjau dari karakteristik subjektif. Namun, perbedaan yang signifikan hanya ditemukan pada variabel tempat tinggal, asupan makan, status gizi, dan indeks prestasi kumulatif dengan nilai signifikansi secara berturut-turut sebesar 0,047, 0,020,0,032, dan 0,009. Perbedaan kadar $\mathrm{Hb}$ yang signifikan juga dijumpai pada variabel status anemia ( $\mathrm{p}=$ 0,040). Sedangkan pada variabel lainnya tidak ditemukan perbedaan yang signifikan pada kadar $\mathrm{Hb}(\mathrm{p}>0,05)$.

Anemia gizi besi merupakan jenis anemia yang paling banyak dijumpai di berbagai negara, dimana sekitar $30 \%$ populasi dunia mengalami anemia jenis ini $^{10}$. Sebagian besar penelitian sebelumnya melaporkan bahwa kejadian anemia banyak dialami oleh responden perempuan, baik anak-anak maupun wanita usia subur ${ }^{19}$. Oleh sebab itu, dalam penelitian ini berfokus terhadap kelompok usia lain yang sama-sama termasuk dalam populasi rentan, yaitu mahasiswi. Dari hasil penelitian didapatkan temuan bahwa prevalensi anemia di kalangan mahasiswi di Kota Surabaya sekitar $26,1 \%$ dengan rerata kadar $\mathrm{Hb}$ sebesar 10,85 $\mathrm{g} / \mathrm{dl}^{20}$. Angka ini tergolong tinggi bila dibandingkan dengan prevalensi anemia pada remaja di Kota Jakarta, yaitu sebesar $13,5 \%$ sebagaimana hasil studi Sumarlan, et al. (2018) pada tahun 2017. WHO menyebutkan bahwa anemia termasuk masalah kesehatan masyarakat yang serius jika prevalensinya berada di atas angka $5 \%$ dalam suatu populasi ${ }^{21}$. Oleh sebab itu, prevalensi anemia di Kota Surabaya masih menjadi concern yang butuh untuk ditangani dengan segera. Dalam penelitian ini, kadar $\mathrm{Hb}$ 
cenderung meningkat seiring dengan bertambahnya usia sekalipun perbedaannya tidak signifikan, dimana mahasiswa yang berusia lebih tua memiliki kadar $\mathrm{Hb}$ yang lebih tinggi dibanding mahasiswa yang berusia lebih muda. Temuan yang sama juga dilaporkan oleh Li et al. (2018) dalam penelitiannya, dimana bertambahnya usia responden diikuti oleh peningkatan kadar $\mathrm{Hb}$. Penelitian juga mencatat bahwa individu yang berada pada kelompok umur lebih muda memiliki kemungkinan yang sama dan bahkan lebih besar untuk memiliki kadar $\mathrm{Hb}$ yang rendah atau berada dalam kisaran angka yang dapat memengaruhi perkembangan kognitifnya ${ }^{22,23}$.

Faktor tempat tinggal juga menjadi salah satu variabel yang berkaitan dengan prevalensi anemia. Penelitian ini menemukan bahwa mahasiswi yang tinggal di kos atau asrama cenderung memiliki kadar $\mathrm{Hb}$ yang lebih rendah dibandingkan dengan yang tinggal bersama orang tua. Hal ini sesuai dengan hasil penelitian Farida (2012) yang menyebutkan bahwa proporsi anemia pada mahasiswi yang tinggal di kos lebih tinggi dibandingkan mahasiswi yang tinggal di rumah orang tua. Temuan ini dikuatkan oleh hasil penelitian lain yang menyebutkan bahwa mahasiswi yang tinggal di kos atau asrama memiliki risiko untuk mengalami anemia 3,115 kali lebih tinggi dibandingkan yang tinggal bersama dengan keluarganya ${ }^{25}$. Penyebab yang melatarbelakangi hal ini banyak terkait dengan pola makan dan kualitas makanan, dimana kebiasaan membeli makanan yang tidak sehat lebih banyak dilakukan oleh mahasiswi yang tinggal di $\operatorname{kos}^{24}$. Pola makan yang baik dan seimbang merupakan hal yang penting bagi setiap orang untuk dapat hidup sehat, terutama bagi remaja yang masih mengejar masa tumbuh ${ }^{26,27}$. Hasil penelitian ini menunjukkan bahwa kadar $\mathrm{Hb}$ yang rendah lebih banyak dijumpai pada mahasiswi yang memiliki asupan makan kurang dari AKG. Banyak faktor yang menyebabkan hal ini terjadi, seperti pola makan yang tidak teratur, tidak sempat sarapan, atau terlalu malas dan lelah untuk menyiapkan makanan sehat ${ }^{2}$. Pola makan sangat berhubungan dengan kejadian anemia, sebab masih banyak dijumpai mahasiswa yang memiliki pola makan tidak sehat, seperti kurang mengonsumsi protein, gemar memakan junk food dan minuman kemasan, serta praktik diet tidak sehat yang banyak mengabaikan asupan zat gizi esensial bagi pertumbuhan dan perkembangan. Pola makan tidak sehat ini menyebabkan mahasiswa tidak dapat memenuhi keanekaragaman zat gizi seperti Fe dan zat lain yang dibutuhkan oleh tubuh untuk proses pembentukan hemoglobin ${ }^{26}$. 
Tabel 2. Pola Menstruasi dan Status Anemia pada Mahasiswa

\begin{tabular}{lccccccc}
\hline \multirow{2}{*}{ Pola Menstruasi } & \multicolumn{2}{c}{ Anemia } & \multicolumn{2}{c}{ Tidak Anemia } & \multicolumn{2}{c}{ Total } & \multirow{2}{*}{-value } \\
\cline { 2 - 6 } & $\mathrm{n}$ & $\%$ & $\mathrm{n}$ & $\%$ & $\mathrm{n}$ & $\%$ & \\
\hline Usia menarche & 5 & 20,0 & 20 & 80,0 & 25 & 27,2 & 0,089 \\
$\quad$ < 12 tahun & 19 & 28,4 & 48 & 71,6 & 67 & 72,8 & \\
$\quad 12$ tahun & 7 & 11,7 & 53 & 88,3 & 60 & 65,2 & 0,031 \\
\hline Siklus menstruasi & 17 & 53,1 & 15 & 46,9 & 32 & 34,8 & \\
$\quad$ Teratur & & & & & & & \\
$\quad$ Tidak teratur & 21 & 25,9 & 60 & 74,1 & 81 & 88,0 & 0,196 \\
\hline Lama menstruasi & 3 & 27,3 & 8 & 72,7 & 11 & 12,0 & \\
$\quad$ Normal (3-8 hari) & & & & & & & \\
$\quad$ Panjang (> 8 hari) & 8 & 40,0 & 12 & 60,0 & 20 & 21,7 & 0,245 \\
\hline Keluhan menstruasi & 16 & 22,2 & 56 & 77,8 & 72 & 78,2 & \\
$\quad$ Ada & & & & & &
\end{tabular}

Hasil analisis terhadap pola menstruasi menunjukkan bahwa mayoritas mahasiswi memasuki masa menstruasi pertama kali pada usia $\geq 12$ tahun (71,6\%), yang mana usia menarche ini termasuk dalam kategori normal (11-14 tahun) bagi perempuan. Sebagian besar mahasiswi yang mengalami menarche di usia ini tidak mengalami anemia (46,9\%). Uji ChiSquare menunjukkan bahwa usia menarche atau menstruasi pertama kali tidak berhubungan dengan kejadian anemia $(\mathrm{p}=0,089)$. Adapun sebagian besar responden memiliki siklus menstruasi yang teratur $(65,2 \%)$, dan anemia lebih banyak dialami oleh mahasiswi yang memiliki siklus menstruasi tidak teratur (53,1\%). Dari hasil uji Chi Square didapatkan informasi bahwa siklus menstruasi berhubungan dengan kejadian anemia pada mahasiswa, dengan nilai $p$-value sebesar 0,031. Sedangkan lama menstruasi $(\mathrm{p}=0,196)$ dan keluhan menstruasi $(\mathrm{p}=0,245)$ tidak berhubungan dengan kejadian anemia, dimana sebagian besar mahasiswi mengalami menstruasi dalam waktu yang normal $(88,0 \%)$ dan tidak mengalami keluhan selama menstruasi $(78,2 \%)$.

Selain disebabkan karena kurangnya asupan, anemia pada mahasiswi juga disebabkan oleh menstruasi ${ }^{6}$. Perdarahan yang terjadi pada saat menstruasi mengakibatkan zat besi dalam darah keluar dari tubuh. Dalam penelitian ini, diperoleh bahwa siklus menstruasi berhubungan dengan kejadian anemia pada mahasiswi. Remaja putri yang memiliki siklus menstruasi pendek memiliki kemungkinan lebih besar untuk kehilangan zat besi dalam jumlah banyak sehingga keseimbangan zat besi dalam tubuh menjadi terganggu ${ }^{28}$. Siklus menstruasi sendiri berbeda-beda pada setiap wanita, sebab banyak dipengaruhi oleh faktor fisik dan psikis, seperti hormon, stres, dan aktivitas fisik yang dilakukan ${ }^{11}$. 
Tabel 3. Hubungan antara Status Anemia dan Prestasi Belajar Mahasiswa

\begin{tabular}{|c|c|c|c|c|c|c|c|}
\hline \multirow{3}{*}{ Status Anemia } & \multicolumn{4}{|c|}{ Indeks Prestasi Akademik } & \multirow{2}{*}{\multicolumn{2}{|c|}{ Total }} & \multirow{3}{*}{$p$-value } \\
\hline & \multicolumn{2}{|c|}{ Cukup $(\leq 3.25)$} & \multicolumn{2}{|c|}{ Baik (> 3.25) } & & & \\
\hline & $\mathrm{n}$ & $\%$ & $\mathrm{n}$ & $\%$ & $\mathrm{n}$ & $\%$ & \\
\hline Anemia $(<12 \mathrm{~g} / \mathrm{dl})$ & 11 & 45,8 & 13 & 54,2 & 24 & 26,1 & 0047 \\
\hline Tidak anemia (> $12 \mathrm{~g} / \mathrm{dl})$ & 13 & 19,1 & 55 & 80,9 & 68 & 73,9 & $0,0+7$ \\
\hline
\end{tabular}

Hasil analisis Chi-Square pada tabel 3 menunjukkan bahwa proporsi anemia pada mahasiswa yang memiliki indeks prestasi cukup $(45,8 \%)$ hampir sama besar dengan proporsi mahasiswa yang memiliki indeks prestasi baik $(54,2 \%)$. Tabulasi silang antara status anemia dan prestasi belajar didapatkan hasil yang signifikan $(\mathrm{p}=0,047)$. Dari hasil ini dapat disimpulkan bahwa kejadian anemia yang dialami oleh mahasiswi berhubungan dengan prestasi belajar yang diukur menggunakan indeks prestasi akademik. Mahasiswi yang tidak anemia memiliki indeks prestasi yang lebih baik dibanding mahasiswi yang anemia.

Rendahnya kadar hemoglobin dan zat besi dalam waktu lama akan menyebabkan anemia. Anemia, yang salah satunya diakibatkan oleh rendahnya kadar zat besi dalam tubuh, berkaitan dengan penurunan saturasi oksigen dalam darah yang menuju ke otak ${ }^{29}$. Hal ini ditengarai menjadi penyebab dari silent cerebral infarct ${ }^{30}$ yang dapat memengaruhi fungsi kognitif dan perkembangan motorik skill ${ }^{31}$. Gangguan pada fungsi kognitif biasanya termanifestasi dalam bentuk kelelahan, daya ingat yang buruk, sulit berkonsentrasi, dan penurunan problem solving ${ }^{32}$. Daya konsentrasi yang rendah akan memengaruhi fokus mahasiswi dalam memahami materi kuliah, sehingga akan berdampak pada performa akademiknya di kelas. Hal ini dibuktikan dengan hasil penelitian ini, dimana status anemia berhubungan dengan indeks prestasi mahasiswa. Temuan ini sejalan dengan penelitian sebelumnya yang menyebutkan bahwa anemia berkaitan dengan buruknya prestasi akademik siswa ${ }^{22}$.

Penelitian lain yang dilakukan Tiongkok sebagai hasil dari controlled trial juga menyebutkan hal serupa, sehingga dapat dipahami bahwa hubungan kausal antara kejadian anemia dan aspek kognitif merupakan suatu hal yang perlu diperhatikan ${ }^{33}$. Selain berpengaruh terhadap fungsi kognitif dan sikap, anemia di kalangan remaja juga berkontribusi terhadap tingginya angka mortalitas, bayi berat lahir rendah (BBLR), dan kematian perinatal ${ }^{34}$. Namun demikian, prestasi belajar mahasiswi tidak hanya dipengaruhi oleh status anemia saja, tetapi juga faktor lain seperti motivasi, cara belajar, dan faktor lingkungan. Sehingga untuk menentukan keterkaitan antara kedua variabel ini diperlukan penelitian lanjutan yang lebih detail dan mendalam. 


\section{SIMPULAN DAN SARAN}

\section{Simpulan}

Prevalensi anemia pada mahasiswi di Kota Surabaya masih cukup tinggi. Beberapa faktor yang berkaitan dengan anemia yaitu tempat tinggal, asupan makan, status gizi, dan siklus menstruasi. Terdapat hubungan yang signifikan antara status anemia dengan prestasi belajar mahasiswa yang diukur menggunakan indeks prestasi akademik. Mahasiswa yang mengalami anemia akan mengalami penurunan daya konsentrasi kurang optimal dalam memahami materi kuliah.

\section{Saran}

Mahasiswi merupakan salah satu kelompok yang rentan mengalami anemia, sehingga sangat penting untuk melakukan berbagai upaya yang dapat meningkatkan kadar $\mathrm{Hb}$ melalui peningkatan asupan makanan tinggi zat besi, mengenali gejala anemia, menandai pola menstruasi, mengonsumsi tablet penambah darah dan perlunya edukasi anemia secara berkala kepada mahasiswa.

\section{REFERENSI}

1. Lestari IP, Lipoeto NI, Almurdi A. Hubungan konsumsi zat besi dengan kejadian anemia pada murid SMP Negeri 27 Padang. J Kesehat Andalas. 2018;6(3):507.

2. Al-Jamea L, Woodman A, Elnagi EA, AlAmri SS, Al-Zahrani AA, Al-Shammari $\mathrm{NH}$, et al. Prevalence of iron-deficiency anemia and its associated risk factors in female undergraduate students at prince sultan military college of health sciences. J Appl Hematol. 2019;10(4):126-33.
3. McClung JP, Marchitelli LJ, Friedl KE, Young AJ. Prevalence of iron deficiency and iron deficiency anemia among three populations of female military personnel in the US Army. J Am Coll Nutr. 2006;25(1):64-9.

4. Ramzi M, Haghpanah S, Malekmakan L, Cohan N, Baseri A, Alamdari A, et al. Anemia and Iron Deficiency in Adolescent School Girls in Kavar Urban Area, Southern Iran. Iran Red Crescent Med J. 2011;13(2):128-33.

5. Wahyuni I. Hubungan kepatuhan konsumsi tablet Fe dengan kejadian anemia pada ibu post partum di wilayah kerja Puskesmas Payung Sekaki Pekanbaru. Med Usada [Internet]. 2019;2(2):32-9. Available from: http://ejournal.stikesadvaita.ac.id/index.ph p/MedikaUsada/article/view/53

6. Al-Alimi AA, Bashanfer S, Morish MA. Prevalence of iron deficiency anemia among university students in Hodeida province, Yemen. Anemia. 2018;2018.

7. Khaskheli MN, Baloch S, Sheeba A, Baloch $\mathrm{S}$, Khaskheli FK. Iron deficiency anaemia is still a major killer of pregnant women. Pakistan J Med Sci. 2016;32(3):630-4.

8. Shill KB, Karmakar P, Kibria MG, Das A, Rahman MA, Hossain MS, et al. Prevalence of iron-deficiency anaemia among university students in Noakhali Region, Bangladesh. J Heal Popul Nutr. 2014;32(1):103-10.

9. Al-Zabedi EM. Prevalence and risk factors of iron deficiency anemia among children in Yemen. Am J Heal Res. 2014;2(5):319.

10. Al Hassan NN. The prevalence of iron deficiency anemia in a Saudi University female students. J Microsc Ultrastruct. 2015;3(1):25-8.

11. Dumilah PRA, Sumarmi S. Hubungan anemia dengan prestasi belajar siswi di SMP unggulan bina insani. Amerta Nutr. 2017;1(4):331.

12. Hidayat N, Sunarti S. Validitas pemeriksaan 
kadar hemoglobin menggunakan metode $\mathrm{Hb}$ meter pada remaja putri di MAN wonosari. Kesmas. 2015;9(1):11-8.

13. Irsa L. Gangguan kognitif pada anemia defisiensi besi. Sari Pediatr. 2002;4(3):1148.

14. Insel P, Turner RE, Ross D. Discovering Nutrition. 3rd Editio. Caanada; 2010.

15. Balitbangkes. Riset Kesehatan Dasar 2013. Jakarta; 2013.

16. Setyono FS. Hubungan tingkat pengetahuan gizi, body image, dan tindakan diet dengan status anemia dan status gizi remaja putri. Universitas Airlangga; 2010.

17. Permatasari T, Briawan D, Madanijah S. Efektivitas program suplementasi zat besi pada remaja putri di kota Bogor. J MKMI. 2018;14(1).

18. Kemenkes. Pesan Untuk Remaja Putri Indonesia: Cantik itu Sehat, Bukan Kurus [Internet]. 2018 [cited 2021 Jan 21]. Available from: https://www.kemkes.go.id/article/view/181 12300003/pesan-untuk-remaja-putriindonesia-cantik-itu-sehat-bukankurus.html

19. Hamali HA, Mobarki AA, Saboor M, Alfeel A, Madkhali AM, Akhter MS, et al. Prevalence of anemia among Jazan university students. Int $\mathrm{J}$ Gen Med. 2020;13:765-70.

20. Sumarlan ES, Windiastuti E, Gunardi H. Iron status, prevalence and risk factors of iron deficiency anemia among 12- to 15year-old adolescent girls from different socioeconomic status in indonesia. Makara J Heal Res. 2018;22(1):46-52.

21. WHO. Iron deficiency anemia: assessment, prevention, and control-a guide for programme managers. Geneva; 2001.

22. Li L, Huang L, Shi Y, Luo R, Yang M, Rozelle S. Anemia and student's educational performance in rural Central China: Prevalence, correlates and impacts. China Econ Rev [Internet].
2018;51(620):283-93. Available from: http://dx.doi.org/10.1016/j.chieco.2017.07. 006

23. Sylvia S, Luo RF, Yue A, Shi YJ, Zhang IH, Martorell R, et al. Anemia and cognition: Are our diagnoses wrong? REAP Work Pap. 2016;Standford,

24. Farida RN. Gambaran dan determinan anemia pada mahasiswi S-1 reguler fakultas kesehatan masyarakat universitas indonesia tahun 2012. Universitas Indonesia; 2012.

25. Leginem. Faktor-faktor yang berhubungan dengan status anemia mahasiswi akademi kebidanan di Kota Banda Aceh tahun 2002. Universitas Indonesia; 2002.

26. Rusman ADP. Pola makan dengan kejadian anemia pada mahasiswi yang tinggal di koskosan. J Ilm Mns dan Kesehat. 2018;1(2):144-51.

27. Simanungkalit SF, Simarmata OS. Pengetahuan dan perilaku konsumsi remaja putri yang berhubungan dengan status anemia. Bul Penelit Kesehat. 2019;47(3):175-82.

28. Arisman MB. Gizi dalam daur kehidupan. Edisi 2. Jakarta: Penerbit Buku Kedokteran EGC; 2010.

29. Hogan AM, Pit-ten Cate IM, VarghaKhadem M, Prengler M, Kirkham FJ. Physiological correlates of intellectual function in children with sickle cell disease: hypoxaemia, hyperaemia and brain infarction. Dev Sci. 2006;9(4):379-87.

30. Dowling MM, Quinn CT, Rogers ZR, Buchanan GR. Acute silent cerebral infarction in children with sickle cell anemia. Pediatr Blood Cancer. 2010;54(3):461-4.

31. Cordeira LS, Wilde PE, Semu H, Levinson FJ. Household food security is inversely associated with undernutrition among adolescents from Kilosa, Tanzania. J Nutr. 2012;142(9):1741-7.

32. Teni M, Shiferaw S, Asefa F. Anemia and its relationship with academic performance 
among adolescent school girls in kebena district, southwest Ethiopia. Biotechnol Heal Sci. 2017;4(1):1-8.

33. Miller G, Luo RF, Zhang LX, Slyvia S, Shi YJ, Foo P, et al. Effectiveness of provider incentives for anaemia reduction in rural China: A cluster randomised trial. Br Med J. 2012;345:e4809.

34. Kulkarni M V., Durge PM, Kasturwar NB. Prevalence of anemia among adolescent girls in an urban slum. Natl J Community Med. 2012;3:108-11. 